\title{
Статьи
}

Пространственная Экономика 2011. № 4. C. $6-22$

УДК 339.5(510)

\section{А. А. Изотов}

\section{ВНЕШНЯЯ ТОРГОВАЯ КИТАЯ: РЕАКЦИЯ НА ИЗМЕНЕНИЕ BAАЮТНОГО KУРСА}

На основе официальных данных китайской и международной статистики оценено воздействие ревальвации юаня на параметры внешней торговли КНР по странам (в том числе с учетом кризисных тенденций в мировой экономике). С помощью регрессионного анализа получены количественные оценки реакций параметров внешней торговли Китая по странам в зависимости от вариантов ревальвации юаня (10\% и $50 \%)$ по отношению к доллару США. Выяснено, что ревальвация юаня ведет к сокращению темпов прироста и экспорта, и импорта КНР в целом, при этом реакции по странам будут различны.

Ревальвация, недооценка, номинальный валютный курс, реальный валютный курс, юань, доллар США, экспорт, импорт, Китай.

\section{ВВЕДЕНИЕ}

С точки зрения теории международной экономики механизм воздействия валютного курса на внешнюю торговлю следующий: при ревальвации национальной валюты растут цены на экспортную продукцию, что ведет к снижению конкурентоспособности и сокращению поставок отечественных товаров на мировой рынок, а импорт из-за относительного снижения цены растет, в результате чего торговый баланс страны ухудшается. Обратная тенденция происходит при девальвации валюты.

Одним из важнейших факторов успешного развития китайской экономики является внешнеторговая и валютная политика, основанная на суще-

(C) Изотов Д. А., 2011

Исследование выполнено при поддержке гранта Президента РФ № MК-4765.2011.6. 
ственной недооценке курса национальной валюты, что в свою очередь способствует увеличению внешней торговли КНР. С 2005 г. по настоящее время Китай проводит постепенное укрепление своей национальной валюты, которое осуществляется в рамках коридора колебаний курса юаня по отношению к корзине валют, основную долю в которой занимает доллар США. Проведение такой валютной политики вызвано объективным ростом потребительских цен и национальных активов, ростом денежной массы в связи с постоянными валютными интервенциями Народного банка Китая на финансовом рынке, трудностью управления огромными золотовалютными резервами и другими причинами. Также страны - ведущие торговые партнеры КНР (США, страны ЕС) требуют провести ревальвацию юаня для снижения огромного отрицательного сальдо торгового баланса с Китаем. Поскольку в последнее десятилетие Китай прочно занял ведущее место в мировой торговле, генерируемые ревальвацией юаня изменения в объемах экспорта и импорта КНР способны привести к неминуемым экономическим последствиям (в первую очередь - внешнеторговым) для стран - основных торговых партнеров Китая.

Несмотря на предпринимаемые меры, связанные с постепенным укреплением юаня, Китай по-прежнему имеет активное сальдо торгового баланса, увеличивая тем самым свои более чем избыточные золотовалютные резервы, которые по итогам первого полугодия 2011 г. достигли новой рекордной величины - 3,2 трлн долл. США.

Безусловно, данное обстоятельство вызывает дискуссии в мировом научном сообществе относительно реальных и потенциальных эффектов текущей и последующей ревальвации юаня. В 2000-е гг. опубликовано достаточно большое количество исследований, касающихся изучения и оценки различного рода последствий от изменения курсовой политики, как для китайской экономики в целом ${ }^{1}$, так и для основных торговых партнеров Китая ${ }^{2}$. Однако в этих исследованиях анализируется взаимосвязь динамики курса юаня (как реального, так и номинального), внешней торговли и других параметров экономики Китая только докризисного периода. Несмотря на то, что кризисные тенденции в мировой экономике способствовали снижению внешней торговли КНР, в исследованиях, посвященных воздействию укрепления юаня на китайский экспорт и импорт, это обстоятельство пока не освещается.

Исходя из вышесказанного, можно предположить следующее: вследствие ревальвации юаня реакции параметров внешней торговли Китая по странам будут существенно различаться, что, возможно, приведет к снижению отрицательного сальдо торгового баланса с ведущими торговыми партнерами КНР.

\footnotetext{
${ }^{1}$ См., напр.: [3; 8].

${ }^{2}$ См., напр.: [12, pp. 19-39; 17, pp. 33-46].
} 
№ 42011

Для проверки данного предположения необходимо: 1) оценить воздействие ревальвации юаня на параметры внешней торговли КНР по странам (в том числе с учетом кризисных тенденций в мировой экономике); 2) получить количественные оценки реакций параметров внешней торговли Китая по странам в зависимости от вариантов ревальвации юаня. В качестве информационной базы исследования выступают данные китайской и международной статистики в юанях $[2 ; 4 ; 5 ; 11 ; 16 ; 19]$.

\section{ВЛИЯНИЕ ДИНАМИКИ ВАЛЮТНОГО КУРСА НА ВНЕШНЕТОРГОВЫЕ ВЗАИМОСВЯЗИ КИТАЯ ПО СТРАНАМ}

Внешняя торговля является одним из ключевых факторов быстрого роста китайской экономики на протяжении более тридцати лет. По состоянию на 2010 г. доля экспорта в ВВП Китая составляет 27\%, импорта - 24\%1 (рuс. 1).

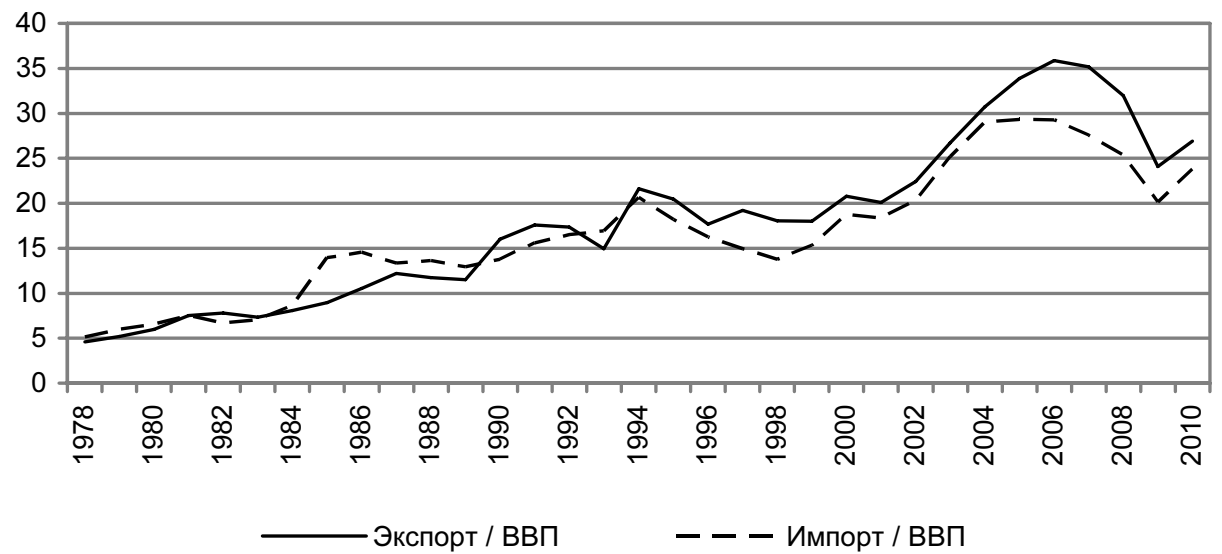

Puc. 1. Отношение экспорта и импорта к ВВП Китая (в юанях), \%

Источники: рассчитано по: [4; 19].

Создание в Китае благоприятных условий для развития внешнеторговой деятельности обеспечивается как различными льготами, так и валютной политикой в части формирования курса юаня. С 1994 г. существенная девальвация и дальнейшая привязка китайской валюты к доллару США обеспечивают рост внешней торговли КНР. Доля китайского экспорта в ВВП

1 Причем высказываются мнения, что по сравнению с другими странами Азии экспортная и импортная квоты Китая не соответствуют (существенно превышают) размеру и уровню развития экономики (по ВВП на душу населения). См.: [7, pp. 455-466]. 
с этого периода времени составляет не менее 20\%, а импорта - не менее 14\%. Недооценка китайской национальной валюты является значительной: номинальный курс юаня превышает реальный по паритету покупательной способности более чем в два раза относительно доллара США (puc. 2).

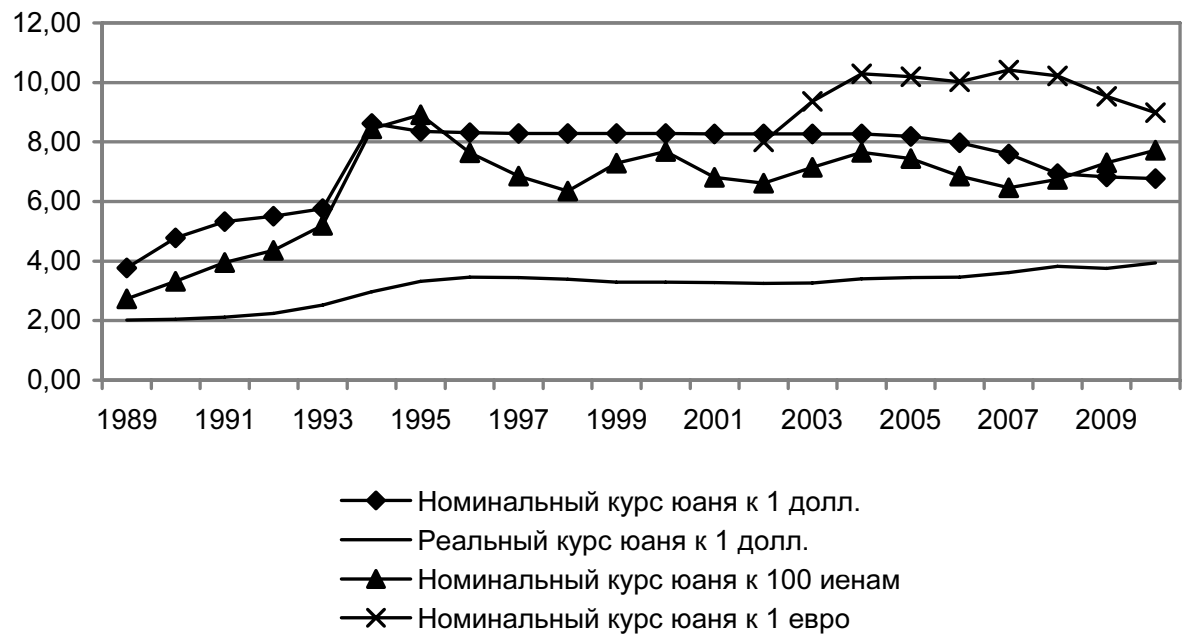

Puc. 2. Реальный курс юаня к доллару США и номинальные курсы юаня к доллару США, евро и иене

Источники: [4; 19].

Формально в Китае диапазон колебаний курса юаня к доллару США установлен на уровне $0,5 \%$ в день. Однако на практике он достигается довольно редко, поскольку курс китайской валюты не является свободно плавающим, а юань не является свободно конвертируемой валютой ${ }^{1}$.

Следует также иметь в виду, что девальвация доллара США ведет к девальвации юаня относительно прочих валют ${ }^{2}$ При девальвации доллара США к евро и иене экспортеры китайской продукции получают ценовое преимущество на европейском и японском рынках, несмотря на укрепление юаня к американской валюте. Текущая поддержка Китаем экономики зоны евро, а также японской экономики путем приобретения государственных обязательств, направлена в том числе на поддержание существующего высокого курса этих валют относительно доллара США, что означает получение преимуществ для экспортеров китайской продукции на рынках этих стран.

1 Тем не менее происходит постепенная ревальвация юаня: в сентябре 2011 г. курс китайской валюты составил 6,4 юаня за доллар США (укрепление за год - 5\%).

2 Подробнее см.: [15, pp. 19-35]. 
1. 2011

Главными импортерами в Китай являются Япония, страны EC, ACEAH, Республика Корея, США и Тайвань (табл. 1).

Таблица 1

Структура импорта по странам (группам стран) - основным торговым партнерам КНР в 2010 г., \%

\begin{tabular}{|c|c|c|c|c|c|c|c|c|c|c|c|}
\hline $\begin{array}{c}\text { Страна } \\
\text { (группа } \\
\text { стран) }\end{array}$ & 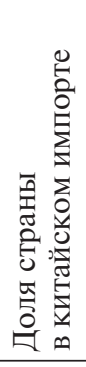 & 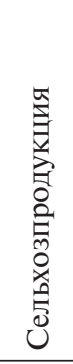 & 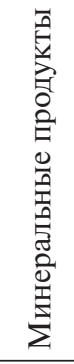 & 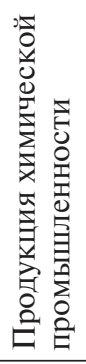 & 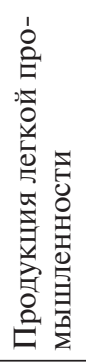 & 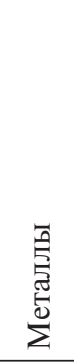 & 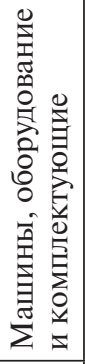 & 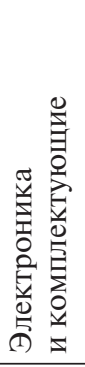 & 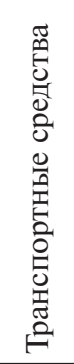 & 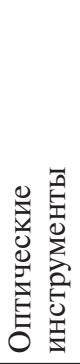 & 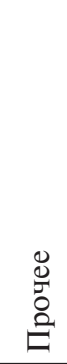 \\
\hline Австралия & 4,4 & 4,0 & 70,0 & 8,0 & 2,0 & 12,0 & 1,0 & 0,2 & 1,0 & 0,1 & 1,7 \\
\hline ACEAH & 11,1 & 7,0 & 21,0 & 10,0 & 4,0 & 3,0 & 17,0 & 36,0 & 0,5 & 1,0 & 0,5 \\
\hline Бразилия & 2,7 & 10,0 & 34,0 & 1,1 & 1,2 & 41,0 & 4,3 & 0,2 & 1,0 & 0,5 & 6,7 \\
\hline Гонконг & 0,9 & 0,6 & 2,5 & 22,3 & 11,2 & 8,1 & 5,4 & 32,2 & 0,1 & 3,7 & 13,9 \\
\hline $\mathrm{EC}$ & 12,1 & 1,5 & 1,6 & 10,0 & 1,3 & 6,7 & 44,4 & 9,1 & 12,8 & 8,2 & 4,4 \\
\hline Индия & 1,5 & 9,2 & 19,5 & 8,4 & 5,0 & 30,5 & 6,4 & 1,0 & 1,0 & 2,0 & 17,0 \\
\hline $\begin{array}{l}\text { Республика } \\
\text { Корея }\end{array}$ & 9,9 & 0,5 & 4,7 & 18,8 & 3,8 & 9,7 & 9,5 & 33,6 & 2,8 & 14,8 & 1,8 \\
\hline Россия & 1,8 & 3,5 & 8,0 & 8,7 & 0 & 6,6 & 1,2 & 0 , & 0,2 & 0 , & 10,5 \\
\hline $\begin{array}{l}\text { Саудовская } \\
\text { Аравия }\end{array}$ & 2,4 & 0 & 94,0 & 5,0 & 0 & 0 & 0,1 & 0 & 0 & 0,1 & 0,8 \\
\hline США & 7,3 & 11,2 & 3,5 & 13,1 & 2,2 & 4,7 & 30,4 & 10,9 & 7,5 & 10,0 & 6,5 \\
\hline Тайвань & 5,2 & 0,4 & 1,2 & 23,6 & 2,8 & 7,5 & 9,0 & 29,0 & 1,1 & 23,0 & 2,4 \\
\hline Япония & 12,7 & 0,2 & 3,5 & 12,8 & 2,4 & 12,3 & 19,1 & 28,3 & 7,0 & 8,9 & 5,5 \\
\hline
\end{tabular}

Источники: $[2 ; 4 ; 5 ; 16]$.

Среди стран-импортеров выделяется ряд стран, специализирующихся в поставках сырья на китайский рынок (доля данной продукции составляет более $10 \%$ в китайском импорте из этих стран): Саудовская Аравия, Австралия, Россия, Индия, Бразилия и страны АСЕАН; сельскохозяйственной продукции - США, Бразилия и Индия; продукции химической промышленности - страны АСЕАН и ЕС, Гонконг, Республика Корея, США, Тайвань, Япония; продукции легкой промышленности - Гонконг, а также Индия; транспортных средств - страны ЕС; оптических инструментов - Тайвань, США и Республика Корея.

Высокая доля (более 10\%) машин и оборудования (товарный код 84 HS) и электроники (товарный код - 85 HS) в китайском импорте харак- 
терна для стран ЕС, АСЕАН, США, Японии, Гонконга, Республики Корея и Тайваня, которая объясняется созданием в КНР предприятий с прямыми иностранными инвестициями (ПИИ) транснациональными корпорациями (ТНК) из данных стран. Доля в общем импорте этих стран по двум товарным группам составляет $28 \%{ }^{1}$.

Таким образом, возможно выделить три группы стран-импортеров. К первой группе относятся Япония, страны ЕС, США, Республика Корея, Тайвань, отчасти Гонконг и страны АСЕАН, продукция которых непосредственно связана с производственными процессами ТНК. Вторую группу формируют импортеры сырьевых товаров: Саудовская Аравия, Австралия, Россия, отчасти Индия, Бразилия и страны АСЕАН. В третью группу входят импортеры, продукция которых конкурирует с китайскими товарами на рынке КНР: Индия, страны АСЕАН и, возможно, Бразилия.

Что касается структуры китайского экспорта, то для большинства представленных в таблице 2 стран основная его доля приходится на две статьи: машины, оборудование и комплектующие, электроника и комплектующие (табл. 2).

Довольно высокая доля (более 10\%) продукции легкой промышленности в китайском экспорте в Австралию, страны ЕС, Республику Корея, Россию, Саудовскую Аравию, США и Японию; продукции химической промышленности - в Бразилию, Индию и Тайвань.

Высокая доля машин, оборудования, электроники и комплектующих в экспорте Китая отмечается по всем странам, представленным в таблице 2. Совокупная доля китайского экспорта по данным товарным группам в ЕС, США, Гонконг ${ }^{2}$ страны АСЕАН, Японию, Республику Корея и Тайвань составляет 42\%. На остальные страны (Австралия, Россия, Саудовская Аравия, Индия и Бразилия) приходится лишь 4,4\%.

Для оценки воздействия валютного курса на внешнюю торговлю КНР в 2004-2010 гг. использовались следующие регрессионные уравнения:

$$
\begin{aligned}
& \Delta I M P_{i}=\beta_{0 i}+\beta_{1} \Delta R A T E_{i}+\beta_{n} \Delta X_{n i}+\varepsilon_{i} \\
& \Delta E X P_{i}=\beta_{0 i}+\beta_{1} \Delta R A T E_{i}+\beta_{n} \Delta X_{n i}+\varepsilon_{i},
\end{aligned}
$$

${ }^{1}$ Производственно-технологический процесс данных предприятий основан на импортируемых комплектующих и инвестиционных товарах с последующим экспортом готовой продукции и комплектующих. В 2010 г. предприятия с ПИИ обеспечивали 55\% экспорта и 53\% импорта КНР. Промышленный выпуск предприятий с ПИИ в ВВП достигает 20\%, несмотря на то, что на них занято только $3 \%$ рабочей силы Китая. Средняя производительность труда на предприятиях с ПИИ в 9 раз выше, чем на национальных предприятиях. Как показывают оценки, предприятия с ПИИ в Китае обеспечивают около $40 \%$ прироста ВВП, т. е. без выпуска данных предприятий экономический рост КНР снизился бы с 9 до 5\% [18, pp. 123-135].

2 Гонконг позиционируется как реэкспортер китайских товаров. Подробно см.: $[9$, pp. 502-520]. 
№ 42011

где $i$ - страна - торговый партнер КНР, $n$ - номер объясняющей переменной, IMP - импорт, EXP - экспорт, $\beta_{0}-$ константа, $R A T E-$ номинальный курс юаня по отношению к доллару США, $X_{n}$ - переменные, отражающие значения других оцениваемых факторов, $\beta_{1}$ и $\beta_{n}-$ значения соответствующих регрессоров, $\varepsilon-$ остаточный член.

Временные ряды показателей сформулированы в темпах прироста $(\Delta X)$ к предыдущему году, т. е. $\Delta X=\frac{X_{t}-X_{t-1}}{X_{t}}$. Полученные в результате расчетов регрессоры характеризуются отсутствием мультиколлинеарности (не имеют значимых коэффициентов парной корреляции) и гетероскедастичности (имеют нулевое математическое ожидание остатков).

Таблица 2

Структура экспорта по странам (группам стран) - основным торговым партнерам КНР в 2010 г., \%

\begin{tabular}{|c|c|c|c|c|c|c|c|c|c|c|c|}
\hline $\begin{array}{r}\text { Стр } \\
\text { (группа }\end{array}$ & 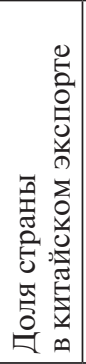 & 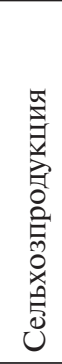 & 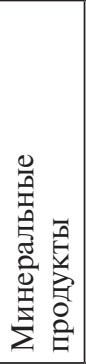 & 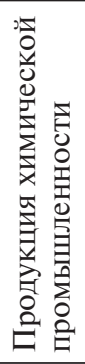 & 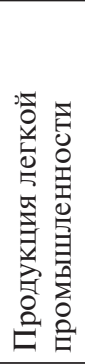 & 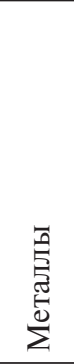 & 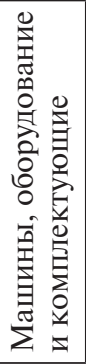 & 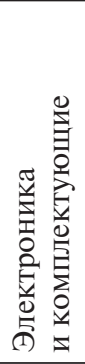 & 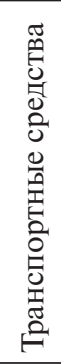 & 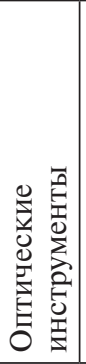 & 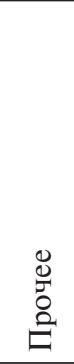 \\
\hline Австраль & 1,7 & 1,0 & 0,1 & 2,1 & 13,0 & 3,0 & 42,0 & 12,0 & 3,0 & 3,0 & 20,8 \\
\hline ACEAH & 8,8 & 0,7 & 2,0 & 9,0 & 8,0 & 4,0 & 25,0 & 30,0 & 3,0 & 4,5 & 13,8 \\
\hline Бразилия & 1,5 & 0,5 & 1,4 & 12,0 & 8,0 & 5,0 & 46,0 & 12,0 & 2,0 & 5,0 & 8,1 \\
\hline Гонконг & 13,8 & 1,8 & 2,5 & 3,1 & 8,9 & 3,1 & 18,7 & 43,3 & 2,8 & 7,5 & 8,3 \\
\hline EC & 19,7 & 1,3 & 0,7 & 4,3 & 15,2 & 3,6 & 43,1 & 15,0 & 3,6 & 3,6 & 9,6 \\
\hline Индия & 2,6 & 0,5 & 1,3 & 19,3 & 5,0 & 1,1 & 49,6 & 10,0 & 1,5 & 2,0 & 9,7 \\
\hline Республ & 4,4 & 4,4 & 1,9 & 8,0 & 16,0 & 3,0 & 43,1 & 17,0 & 3,0 & 3,3 & 0,3 \\
\hline Россия & 1,9 & 3,3 & 1,1 & 5,1 & 19,7 & 6,2 & 32,7 & 10,2 & 2,7 & 4,0 & 15,0 \\
\hline $\begin{array}{l}\text { Саудовская } \\
\text { Аравия } \\
\end{array}$ & 0,6 & 4,0 & 0,2 & 4,0 & 20,0 & J & 38,0 & 15,0 & 3,0 & 2,0 & 8,3 \\
\hline США & 18,0 & 1,3 & 0,5 & 4,4 & 12,2 & 3,4 & 45,8 & 13,7 & 2,3 & 3,2 & 13,2 \\
\hline Тайвань & 2,3 & 1,4 & 3,4 & 13,8 & 3,3 & 10,4 & 14,1 & 40,7 & 1,9 & 5,5 & 5,5 \\
\hline Япония & 7,7 & 6,9 & 4,6 & 6,3 & 20,0 & 7,2 & 17,1 & 19,0 & 3,4 & 3,3 & 12,2 \\
\hline
\end{tabular}

Источники: [2; 4; 5; 16].

Полученные регрессионные оценки отражены в таблицах 3 и 4. К зависимым переменным уравнений (1) и (2) относятся: IMP - импорт Китая в целом, $E U_{-} I-$ импорт из стран Европейского союза (27 стран) в Китай, 
$A U S \_I$ - импорт из Австралии в Китай, $H K_{-} I$ - импорт из Гонконга в Китай, $J P \_I-$ импорт из Японии в Китай, KR_I - импорт из Республики Корея в Китай, $A S E A N \_I-$ импорт из стран АCEАН в Китай, US_I - импорт из США в Китай, $I N \_I-$ импорт из Индии в Китай, $R U_{-} I-$ импорт из России в Китай, $S A R \_I-$ импорт из Саудовской Аравии в Китай, $B R \_I-$ импорт из Бразилии в Китай, $T W_{-} I-$ импорт из Тайваня в Китай; $E X P$ - экспорт Китая в целом, $E U_{-} E-$ экспорт Китая в страны Европейского союза, $A U S \_E-$ экспорт Китая в Австралию, $H K \_E-$ экспорт Китая в Гонконг, $J P \_E-$ экспорт Китая в Японию, $K R \_E-$ экспорт Китая в Республику Корея, US_E - экспорт Китая в США, IN_E - экспорт Китая в Индию, $A S E A N \_E-$ экспорт Китая в страны АCEAH, $R U_{-} E-$ экспорт Китая в Россию, $S A R \_E-$ экспорт Китая в Саудовскую Аравию, $B R \_E-$ экспорт Китая в Бразилию, $T W_{-} E-$ экспорт Китая в Тайвань.

К другим оцениваемым факторам уравнений (1) и (2) относятся: GDPВВП, INV - инвестиции в основные фонды, INVINT - национальные инвестиции в основные фонды, $M A N U F$ - объемы промышленного производства, MANUFFE - объемы промышленного производства предприятий с ПИИ, CONSUMP - расходы на конечное потребление, CONSUMPH - расходы домашних хозяйств на конечное потребление, CONSUMPG - государственные расходы на конечное потребление, TRADE - объемы внутренней торговли, CONSTAX - налог на потребление, TARIFF - средняя ставка таможенной пошлины, $M 2$ - наличные деньги и срочные депозиты в банках (денежный агрегат M2). Для оценки влияния мирового финансового кризиса на показатели внешней торговли используется фиктивная переменная CRIZ, принимающая значение равное единице для 2009 г. ${ }^{1}$

Согласно оценкам регрессионных уравнений (1), воздействие темпов прироста курса юаня к доллару США на темпы приростов импорта Китая является значимым (табл. 3).

Можно отметить, что прирост курса юаня вызывает противоположные реакции на приросты импорта КНР по странам. Так, можно выделить ряд стран (Саудовская Аравия, Бразилия и Индия), для которых рост объемов импорта в Китай зависит от ревальвации юаня и от снижения таможенных пошлин КНР. Это дает основание предполагать, что продукция из этих стран (товары из Бразилии и Индии, поставки нефти и нефтепродуктов из Саудовской Аравии в условиях политики диверсификации поставок энергоносите-

1 Хотя мировой финансовый кризис начался в третьем квартале 2008 г., макроэкономические показатели КНР для данного года не показали снижения из-за быстрого их роста в первом и во втором кварталах. Наиболее информативной стала статистика для 2009 г., по итогам которого объем внешней торговли по отношению к предыдущему году сократился довольно существенно (экспорт сократился на $18 \%$, импорт - на 14\%). По этой причине фиктивная переменная была введена только для 2009 г. 
№ 42011

лей китайским правительством) может получить конкурентные преимущества на внутреннем рынке Китая.

Для остальных рассматриваемых стран ревальвация юаня означает сокращение объемов импорта в Китай. Это можно объяснить тем, что продукция этих стран в основном представлена комплектующими и инвестиционными товарами ТНК, товарами ресурсной группы, импортируемыми по долгосрочным контрактам, а также товарами, поставляемыми по разовым контрактам. В наибольшей степени это характерно для стран АCEAН, Гонконга и Тайваня ${ }^{1}$, в наименьшей - для США, Австралии, стран ЕС, России, Японии и Республики Корея².

Таблица 3

Факторы регрессии, оказывающие воздействие на темпы приростов импорта Китая по странам, где $\beta_{1}$ - темп прироста курса юаня к доллару CША (RATE)

\begin{tabular}{|c|c|c|c|c|c|c|c|c|c|c|c|c|c|}
\hline $\begin{array}{c}\text { Зависимая } \\
\text { перемен- } \\
\text { ная }\end{array}$ & $\beta_{0}$ & $\mathrm{p}_{0}$ & $\beta_{1}$ & $\mathrm{p}_{1}$ & $\mathrm{X}_{2}$ & $\beta_{2}$ & $\mathrm{p}_{2}$ & $X_{3}$ & $\beta_{3}$ & $\mathrm{p}_{3}$ & $\mathrm{R}^{2}$ & DW & $\mathrm{F}$ \\
\hline$I M P$ & - & - & 3,09 & 0,05 & $G D P$ & 1,74 & 0,01 & CRIZ & $-0,22$ & 0 & 0,82 & 1,71 & 0,03 \\
\hline$E U_{-} I$ & - & - & 2,04 & 0,07 & M2 & 1,49 & 0,01 & CRIZ & $-0,43$ & 0 & 0,63 & 2,20 & 0,08 \\
\hline AUS_I & - & - & 1,66 & 0,08 & $I N V$ & 1,53 & 0,00 & CRIZ & $-0,37$ & 0 & 0,68 & 1,35 & 0,06 \\
\hline$H K \_I$ & $-0,3$ & 0,1 & 3,18 & 0,07 & CONSUMPG & 3,07 & 0,05 & - & - & - & 0,60 & 1,73 & 0,10 \\
\hline$J P_{-} I$ & - & - & 2,17 & 0,03 & CONSTAX & 1,31 & 0,00 & CRIZ & $-1,22$ & 0 & 0,74 & 1,64 & 0,03 \\
\hline$K R \_I$ & - & - & 2,58 & 0,02 & MANUFFE & 1,08 & 0,00 & CRIZ & $-0,07$ & 0 & 0,72 & 1,43 & 0,04 \\
\hline$U S \_I$ & - & - & 1,81 & 0,01 & $I N V$ & 0,90 & 0,00 & CRIZ & $-0,29$ & 0 & 0,73 & 1,69 & 0,04 \\
\hline$I N \_I$ & - & - & $-3,72$ & 0,02 & TARIFF & $-10,9$ & 0,01 & CRIZ & $-0,41$ & 0 & 0,70 & 2,13 & 0,05 \\
\hline$A S E A N \_I$ & - & - & 3,83 & 0,04 & $I N V$ & 1,30 & 0,02 & CRIZ & $-0,42$ & 0 & 0,62 & 1,54 & 0,08 \\
\hline$R U_{-} I$ & - & - & 2,73 & 0,06 & CONSUMP & 1,77 & 0,00 & CRIZ & $-0,23$ & 0 & 0,73 & 2,27 & 0,03 \\
\hline$S A R \_I$ & - & - & $-6,16$ & 0,00 & TARIFF & $-8,21$ & 0,00 & CRIZ & $-0,37$ & 0 & 0,77 & 1,65 & 0,02 \\
\hline$B R \_I$ & - & - & $-5,82$ & 0,00 & TARIFF & $-9,33$ & 0,02 & CRIZ & $-0,18$ & 0 & 0,62 & 1,98 & 0,09 \\
\hline$T W_{-} I$ & - & - & 5,33 & 0,04 & MANUF & 2,23 & 0,02 & CRIZ & $-0,19$ & 0 & 0,82 & 1,86 & 0,03 \\
\hline
\end{tabular}

Источник: расчеты автора.

Проведенный анализ показал, что финансовый кризис оказал общее негативное воздействие на импортные поставки товаров на китайский рынок. В наибольшей степени это коснулось Японии, стран ЕC, АСЕАН, Тайваня и США - поставщиков инвестиционных товаров и комплектующих, а также

${ }^{1}$ Подобные результаты были получены в исследовании [13].

2 Анализ по укрупненным товарным группам (двузначный код HS) экспорта и импорта позволяет получить общие оценки взаимосвязи курса юаня и внешней торговли КНР. Колебания регрессоров уравнений (1) и (2) объясняются широким ассортиментом товаров, который отражается в более детализированной структуре экспорта и импорта (например, восьмизначным и десятизначным кодами HS). 
Индии, Австралии и Саудовской Аравии - поставщиков сырьевых товаров; в наименьшей - Республики Корея, Бразилии и России. Единственным исключением является импорт в Китай из Гонконга, для которого фиктивная переменная по 2009 г. статистически незначима.

Согласно полученным оценкам регрессионных уравнений (2), изменение темпов прироста курса юаня по отношению к доллару оказывает значимое воздействие на темпы приростов экспорта Китая (табл. 4).

Таблица 4

Факторы регрессии, оказывающие воздействие на темпы приростов экспорта Китая по странам, где $\beta_{1}$ - темп прироста курса юаня к доллару CША (RATE)

\begin{tabular}{l|c|c|c|c|c|c|c|c|c|c|c}
\hline $\begin{array}{c}\text { Зависимая } \\
\text { переменная }\end{array}$ & $\beta_{1}$ & $\mathrm{p}_{1}$ & $\mathrm{X}_{2}$ & $\beta_{2}$ & $\mathrm{p}_{2}$ & $\mathrm{X}_{3}$ & $\beta_{3}$ & $\mathrm{p}_{3}$ & $\mathrm{R}^{2}$ & $\mathrm{DW}$ & $\mathrm{F}$ \\
\hline$E X P$ & 3,67 & 0,00 & $G D P$ & 2,00 & 0 & $C R I Z$ & $-0,27$ & 0 & 0,93 & 2,09 & 0,00 \\
\hline$E U \_E$ & 4,16 & 0,02 & $G D P$ & 2,29 & 0 & $C R I Z$ & $-0,31$ & 0 & 0,84 & 1,76 & 0,01 \\
\hline$A U S \_E$ & 2,24 & 0,01 & $I N V I N T$ & 1,23 & 0 & $C R I Z$ & $-0,43$ & 0 & 0,88 & 2,09 & 0,01 \\
\hline$H K \_E$ & 4,57 & 0,00 & $G D P$ & 1,85 & 0 & $C R I Z$ & $-0,20$ & 0 & 0,94 & 2,54 & 0,00 \\
\hline$J P \_E$ & 2,62 & 0,05 & $G D P$ & 1,18 & 0 & $C R I Z$ & $-0,21$ & 0 & 0,82 & 1,41 & 0,01 \\
\hline$K R \_E$ & 1,66 & 0,08 & MANUF & 1,67 & 0 & $C R I Z$ & $-0,32$ & 0 & 0,95 & 2,09 & 0,00 \\
\hline$U S \_E$ & 4,57 & 0,00 & $G D P$ & 1,91 & 0 & $C R I Z$ & $-0,20$ & 0 & 0,89 & 2,47 & 0,00 \\
\hline$I N \_E$ & 4,06 & 0,05 & $G D P$ & 3,33 & 0 & $C R I Z$ & $-0,26$ & 0 & 0,78 & 2,04 & 0,02 \\
\hline$A S E A N \_E$ & 3,11 & 0,00 & $G D P$ & 2,01 & 0 & $C R I Z$ & $-0,18$ & 0 & 0,95 & 1,63 & 0,00 \\
\hline$R U \_E$ & 6,54 & 0,01 & $G D P$ & 3,71 & 0 & $C R I Z$ & $-0,65$ & 0 & 0,83 & 2,22 & 0,01 \\
\hline$S A R \_E$ & 3,87 & 0,01 & $T R A D E$ & 2,41 & 0 & $C R I Z$ & $-0,37$ & 0 & 0,87 & 1,41 & 0,01 \\
\hline$B R \_E$ & 3,99 & 0,08 & $C O N S U M P H$ & 4,96 & 0 & $C R I Z$ & $-0,68$ & 0 & 0,80 & 1,67 & 0,02 \\
\hline$T W \_E$ & 5,68 & 0,02 & $G D P$ & 2,34 & 0 & $C R I Z$ & $-0,30$ & 0 & 0,79 & 2,14 & 0,02 \\
\hline
\end{tabular}

Источник: расчеты автора.

Следует отметить, что для темпов прироста экспорта КНР в Россию, Тайвань, Гонконг, США, ЕС, Индию, Бразилию и Саудовскую Аравию значения $\beta_{1}$ превышают значение соответствующего коэффициента для китайского экспорта в целом. Прирост экспорта Китая в эти страны довольно сильно зависим от прироста курса юаня по отношению к доллару: сокращение прироста на 1 п. п. (ревальвационный процесс) приводит к сокращению приростов китайского экспорта на 6,54 п. п. - в российском направлении и на 3,87 п. п. - в случае Саудовской Аравии. Прирост курса юаня по отношению к доллару оказывает меньшее влияние на приросты экспорта китайских товаров в Австралию, Японию, страны АСЕАН и Республику Корея по сравнению с реакцией общего экспорта КНР. Что касается других факторов $\left(X_{n}\right)$, то значимыми оказались переменные, характеризующие рост китайской эко- 
№ 42011

номики (промышленный выпуск, инвестиции в основные фонды, внутреннее потребление и торговля).

Здесь же следует отметить, что финансовый кризис оказал общее негативное воздействие на китайский экспорт по странам. Наибольшее негативное воздействие кризис оказал на темпы прироста китайского экспорта в Бразилию, Россию, Австралию, Саудовскую Аравию, Индию, а также страны ЕС, Республики Корея и Тайвань. Наименьшее воздействие кризисных тенденций в мировой экономике коснулось китайского экспорта в такие страны/ группы стран, как АСЕАН, США, Гонконг и Япония.

Таким образом, ревальвация юаня ведет к сокращению и экспорта, и импорта КНР в целом, при этом импорт из Индии, Бразилии и Саудовской Аравии может возрасти. Вместе с тем ревальвация юаня ведет к снижению импорта из остальных рассматриваемых стран.

\section{КОЛИЧЕСТВЕННЫЕ ОЦЕНКИ РЕАКЦИЙ ПАРАМЕТРОВ ВНЕШНЕЙ ТОРГОВЛИ КИТАЯ ПО СТРАНАМ В ЗАВИСИМОСТИ ОТ ВАРИАНТОВ РЕВАЛЬВАЦИИ ЮАНЯ}

Далее, целесообразно проверить реакцию параметров внешней торговли в зависимости от изменения уровней ревальвации юаня ${ }^{1}$. Можно выделить как минимум два уровня ревальвации юаня: минимальный определяется текущей динамикой курса юаня, максимальный - требованиями ведущих торговых партнеров КНР.

Среднегодовой темп прироста курса юаня к доллару США в 20042010 гг. составил 2,8\%. Наибольшее значение ревальвации - 10\% - наблюдалось в 2008 г., которое являлось самым высоким за тридцать лет. В период кризисных тенденций в мировой экономике (вторая половина 2008 г. - первая половина 2009 г.) курс китайской валюты стабилизировался на отметке 6,8 юаня за доллар США. Однако после этого ревальвация юаня к доллару составляла менее $1 \%$ в 2010 г, увеличившись далее по итогам двух кварталов 2011 г. до 6,5\%. Таким образом, можно предположить, что годовая ревальвация юаня не превысит 10\%, поскольку предшествующая динамика курса китайской валюты не превышала этого значения.

Что касается максимального уровня ревальвации китайской валюты, то наиболее «жестким» параметром может послужить курс юаня к доллару по ППС, который в 2010 г. составлял 3,2 юаня за доллар США [19], что соответствует $50 \%$ ревальвации китайской валюты. Несмотря на то, что это значение

\footnotetext{
${ }^{1}$ Варианты тождественны рассмотренным в предыдущем исследовании [1, с. 44].
} 
ревальвации выше уровня, который требуют от Китая США (40\%), оно будет использовано как максимальное.

Таким образом, в качестве минимально возможного уровня ревальвации юаня к доллару в расчетах будет использоваться $10 \%$, максимального - $50 \%$.

Следует заметить, что полученные коэффициенты регрессии (см. табл. 3, 4), отражающие влияние прироста курса юаня на приросты показателей внешней торговли, имеют довольно высокие значения, что означает высокую чувствительность внешней торговли к динамике курса юаня. При минимальном уровне ревальвации и нулевых приростах других независимых переменных $\left(X_{n}\right)$ уравнений 1 и 2 полученные варианты изменения темпов приростов экспорта и импорта не соответствуют реальной ситуации (табл. 5).

Таблииа 5

Изменения приростов экспорта и импорта КНР при минимальной и максимальной ревальвации юаня при нулевых приростах других независимых переменных, \%

\begin{tabular}{|c|c|c|c|c|}
\hline \multirow[b]{2}{*}{ Страна (группа стран) } & \multicolumn{2}{|c|}{ Импорт } & \multicolumn{2}{|c|}{ Экспорт } \\
\hline & $\begin{array}{c}10 \% \\
\text { ревальвация }\end{array}$ & $\begin{array}{c}50 \% \\
\text { ревальвация }\end{array}$ & $\begin{array}{c}10 \% \\
\text { ревальвация }\end{array}$ & $\begin{array}{c}50 \% \\
\text { ревальвация }\end{array}$ \\
\hline KHP & $-5,3$ & $-26,3$ & $-6,6$ & $-33,0$ \\
\hline Австралия & $-5,5$ & $-27,4$ & $-4,7$ & $-23,5$ \\
\hline ACEAH & $-6,1$ & $-30,6$ & $-6,5$ & $-32,7$ \\
\hline Бразилия & 16,3 & 81,5 & $-16,8$ & $-83,8$ \\
\hline Гонконг & $-2,2$ & $-11,1$ & $-6,4$ & $-32,0$ \\
\hline $\mathrm{EC}$ & $-3,1$ & $-15,3$ & $-8,3$ & $-41,6$ \\
\hline Индия & 10,0 & 50,2 & $-17,1$ & $-85,3$ \\
\hline Республика Корея & $-4,1$ & $-20,6$ & $-3,0$ & $-14,9$ \\
\hline Россия & $-3,5$ & $-17,7$ & $-19,6$ & $-98,1$ \\
\hline Саудовская Аравия & 18,5 & 92,4 & $-8,5$ & $-42,6$ \\
\hline США & $-2,5$ & $-12,7$ & $-6,9$ & $-34,3$ \\
\hline Тайвань & $-9,6$ & $-48,0$ & $-10,2$ & $-51,1$ \\
\hline Япония & $-2,4$ & $-11,9$ & $-2,1$ & $-10,5$ \\
\hline
\end{tabular}

Источник: расчеты автора.

В действительности при текущей ревальвации юаня, которая наблюдается с 2005 г. по настоящее время, темп прироста показателей внешней торговли КНР не снижается, что можно объяснить воздействием на параметры внешней торговли других факторов, нивелирующих негативное влияние укрепления юаня. Для получения более адекватных количественных оценок изменения экспорта и импорта КНР вследствие ревальвации юаня необхо- 
№ 42011

димо в расчетах учитывать сложившуюся динамику других факторов. В итоге была получена количественная оценка изменения экспорта и импорта Китая по странам в рамках двух вариантов, с учетом изменения других независимых переменных: первый - при минимальной ревальвации юаня; второй при максимальной (табл. 6).

Таблица 6

Изменения приростов экспорта и импорта КНР в зависимости от уровней ревальвации юаня с учетом изменения других независимых переменных, \%

\begin{tabular}{l|c|c|c|c}
\hline \multirow{2}{*}{ Страна (группа стран) } & \multicolumn{2}{|c|}{ Импорт } & \multicolumn{2}{c}{ Экспорт } \\
\cline { 2 - 5 } & 1 вариант & 2 вариант & 1 вариант & 2 вариант \\
\hline КНР & $-0,2$ & $-21,2$ & $-0,5$ & $-26,9$ \\
\hline Австралия & 8,2 & $-13,8$ & 2,5 & $-16,3$ \\
\hline АСЕАН & $-0,5$ & $-25,0$ & 0,6 & $-25,5$ \\
\hline Бразилия & 21,5 & 86,7 & 10,3 & $-56,7$ \\
\hline Гонконг & 1,0 & $-7,9$ & $-2,0$ & $-27,6$ \\
\hline ЕС & 1,2 & $-11,1$ & $-0,5$ & $-33,8$ \\
\hline Индия & 15,9 & 56,1 & 6,7 & $-61,5$ \\
\hline Республика Корея & $-0,3$ & $-16,8$ & 2,1 & $-9,8$ \\
\hline Россия & $-0,6$ & $-14,8$ & $-0,7$ & $-79,2$ \\
\hline Саудовская Аравия & 23,4 & 97,3 & 0,1 & $-34,1$ \\
\hline США & 0,9 & $-9,3$ & $-2,0$ & $-29,4$ \\
\hline Тайвань & $-2,8$ & $-41,1$ & $-3,1$ & $-44,0$ \\
\hline Япония & 1,6 & $-7,9$ & $-0,5$ & $-8,9$ \\
\hline
\end{tabular}

Примечание. В расчетах использовались значения темпов приростов показателей, рассчитанные как среднеарифметические за период 2004-2010 гг.: GDP - 17\%, INVINT - 28\%, MANUF - 17\%, TRADE - 16\%, CONSUMPH - 13\%, M2 - 19\%, INV - 27\%, CONSUMPG - 15\%, CONSTAX - 28\%, MANUFFE - 22\%, TARIFF - -2\%, CONSUMP - $13 \%$.

Источник: расчеты автора.

В соответствии с расчетами при первом варианте (при минимальной ревальвации курса юаня с учетом изменения других независимых переменных) прирост экспорта Китая может сократиться на 0,5\%, а импорта - лишь на 0,2\%. В рамках первого варианта темпы прироста китайского экспорта в Австралию, Республику Корея, Индию, Саудовскую Аравию, Бразилию, а также в страны АСЕАН возрастут; в США, Гонконг, Тайвань, Россию и страны EC - сократятся. Минимальная ревальвация китайской валюты с учетом изменения других независимых переменных вызовет сокращение темпов прироста импорта в Китай из Тайваня, Республики Корея, России и стран ACЕАН. Темпы прироста импорта в Китай из Бразилии, Саудовской Аравии и Индии увеличатся. 
При втором варианте (при максимальной ревальвации курса юаня с учетом изменения других независимых переменных) сокращение внешней торговли КНР будет весьма ощутимым: темп прироста экспорта может сократиться на 26,9\%, а импорта - на 21,2\%. Существенные сокращения от ревальвации юаня коснутся темпов приростов китайского экспорта в Россию, Бразилию, Индию, Тайвань, в США, страны ЕС, Гонконг и Саудовскую Аравию. Наименьшее негативное воздействие будет наблюдаться для китайского экспорта в Японию, Республику Корея и Австралию. Это можно объяснить более тесным взаимодействием Японии и Республики Корея с китайской экономикой, в отличие от стран, перечисленных выше. Что касается Австралии, то данная реакция объясняется увеличением в последнее время экспорта китайского оборудования в условиях роста привлечения прямых инвестиций из КНР в разработку австралийских природных ресурсов.

Как показывают оценки, в рамках второго варианта произойдет сокращение китайского импорта практически по всем странам, за исключением импорта из Саудовской Аравии $(97,3 \%)$, Бразилии $(86,7 \%)$ и Индии $(56,1 \%)$. Это является вполне логичным, поскольку потребительские и инвестиционные товары из Индии и Бразилии, которые постепенно становятся конкурентами китайской продукции на мировом рынке, получат ценовые преимущества. Рост поставок нефти и нефтепродуктов в Китай из Саудовской Аравии будет объясняться относительным увеличением цен на топливные ресурсы на внутреннем рынке КНР.

Рассчитанные варианты воздействия ревальвации юаня (с учетом других независимых переменных) позволяют получить изменения объемов экспорта и импорта Китая по странам, которые, в свою очередь, позволят проверить справедливость тезиса о снижении странами - ведущими торговыми партнерами отрицательного сальдо торгового баланса с Китаем. В качестве исходных объемов экспорта и импорта использовались значения по состоянию на 2010 г. (рис. 3a). В соответствии с расчетами в первом варианте (в случае минимальной ревальвации юаня с учетом других независимых переменных) наблюдается лишь несущественное изменение объемов экспорта и импорта КНР по странам (рис. 3б).

Во втором варианте (при максимальной ревальвации юаня) объемы экспорта по странам довольно сильно сократятся (за исключением Республики Корея и Японии). Несмотря на то, что были обнаружены наибольшие сокращения прироста китайского экспорта в Россию, Индию и Бразилию, снижение объемов экспорта в данные страны не столь заметно (рис. 3в) ввиду относительно малых масштабов их торговли с КНР. Ввиду больших объемов экспорта и импорта наибольшее сокращение внешней торговли Китая будет с США, странами ЕС, Гонконгом и АСЕАН. 


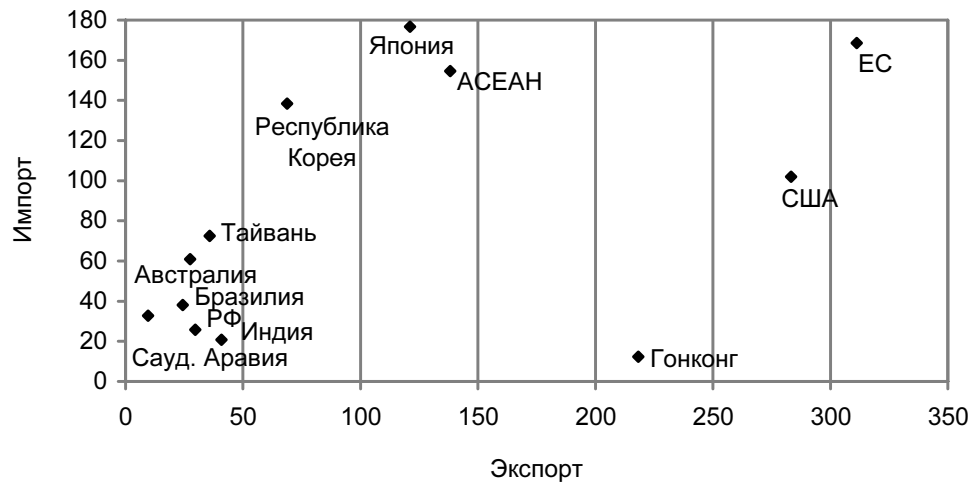

a)

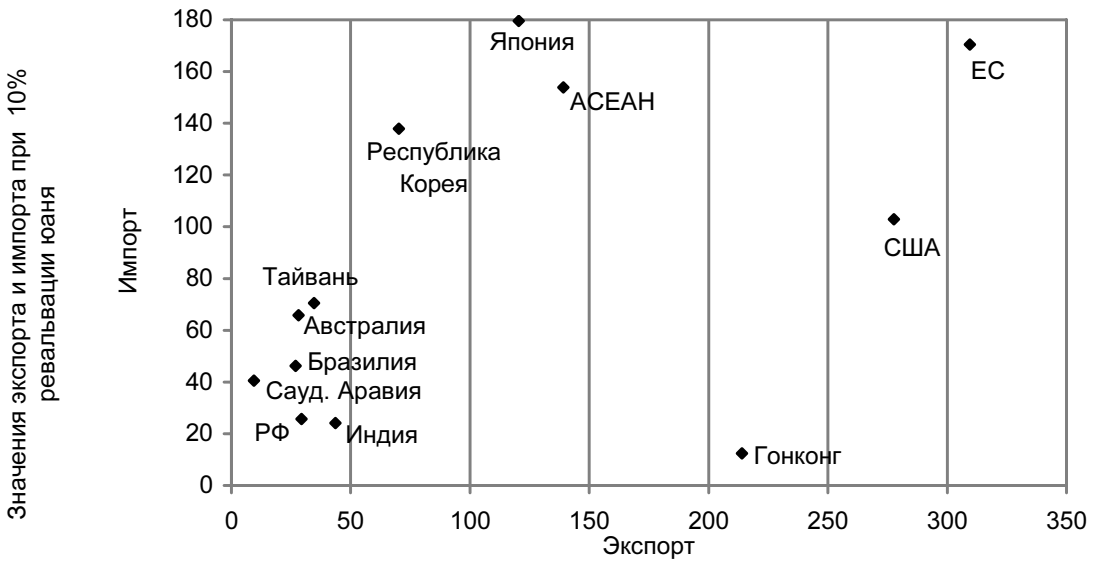

б)

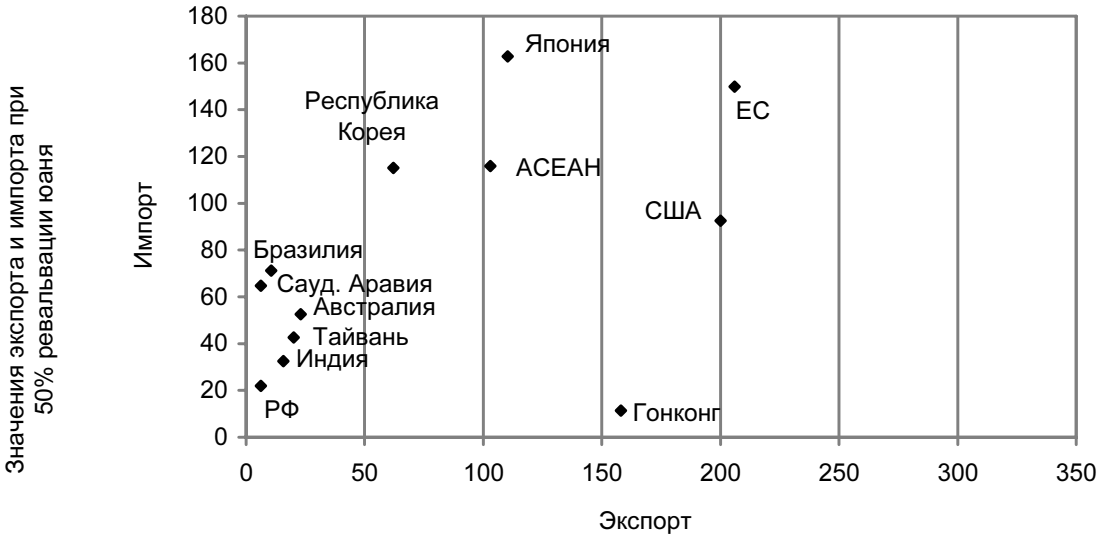

B)

Puc. 3. Предполагаемые объемы экспорта и импорта КНР по странам (база - 2010 г.) в случае ревальвации юаня на $10 \%$ и $50 \%$ к доллару США (при учете других независимых переменных), млрд долл.

Источник: расчеты автора. 
Как показывают оценки, даже при наиболее «жестком» варианте ревальвации юаня (при учете других независимых переменных) положительное сальдо торгового баланса Китая с США и странами ЕС сохранится.

\section{ЗАКЛЮЧЕНИЕ}

Произведенная оценка реакций экспорта и импорта Китая по странам в зависимости от ревальвации юаня по отношению к доллару позволяет сделать следующие выводы.

Во-первых, ревальвация юаня ведет к сокращению темпов прироста и экспорта, и импорта КНР в целом, при этом темпы прироста импорта из Индии, Бразилии и Саудовской Аравии могут возрасти. Для остальных рассматриваемых стран ревальвация юаня означает сокращение темпов прироста импорта в Китай. Это можно объяснить тем, что продукция этих стран в основном представлена комплектующими и инвестиционными товарами ТНК, товарами ресурсной группы, импортируемыми по долгосрочным контрактам, а также товарами, поставляемыми по разовым контрактам.

Во-вторых, общее негативное воздействие финансового кризиса на темпы прироста экспорта и импорта Китая проявилось в 2009 г. В наибольшей степени это коснулось темпа прироста импорта из Японии, стран ЕС, АСЕАН, Тайваня и США - поставщиков инвестиционных товаров и комплектующих, а также Индии, Австралии и Саудовской Аравии - поставщиков сырьевых товаров; в наименьшей - Республики Корея, Бразилии и России. Наибольшее негативное воздействие кризис оказал на темпы прироста китайского экспорта в Бразилию, Россию, Австралию, Саудовскую Аравию, Индию, страны ЕС, Республику Корея и Тайвань; наименьшее - коснулось темпов прироста китайского экспорта в такие страны (группы стран), как АСЕАН, США, Гонконг и Япония.

В-третьих, как показывают расчеты, минимальная ревальвация юаня неспособна сократить объемы экспорта и импорта как Китая в целом, так и с большинством стран ввиду нивелирующего действия других учитываемых в расчетах факторов. Максимальная ревальвация юаня может способствовать существенному сокращению параметров внешней торговли КНР. Это в какой-то мере подтверждает справедливость требований к китайским властям со стороны США и стран ЕС ревальвировать юань - но только отчасти: экспорт Китая в эти страны может сократиться, однако сократится и импорт из них, поскольку экономики этих стран взаимозависимы (большая часть китайского экспорта и импорта обеспечивается ТНК и является средством поддержания их производственного процесса). Тем не менее выровнять торговый баланс этим странам не удастся. 


\section{СПИСОК ЛИТЕРАТУРЫ}

1. Изотов Д. А., Суслов Д. В. Валютный курс и внешняя торговля КНР // Пространственная экономика. 2009. № 3. С. 36-63.

2. CEIC China Database. URL: http://www.ceicdata.com/China.html (дата обращения: 14.08.2011).

3. Chen R., Dao M. The Real Exchange Rate and Employment in China. IMF Working Paper. WP/11/148. June 2011. 50 p.

4. China Statistical Yearbooks 2000-2010. Beijing: China Statistics Press, 2000-2010.

5. China Trade and External Economic Statistical Yearbook 2011. Beijing: China Statistics Press, 2011.

6. Dean J. M., Lovely M. E., Mora J. Decomposing China-Japan-U.S. Trade: Vertical Specialization, Ownership, and Organizational Form // Journal of Asian Economics. 2009. Vol. 20. № 6. Pp. 596-610.

7. Edmonds C., La Croix S., Li Y. China trade: Busting gravity's bounds // Journal of Asian Economics. 2008. Vol. 19. № 5-6. Pp. 455-466.

8. Eichengreen B., Park D., Shin K. When Fast Growing Economies Slow Down: International Evidence and Implications for China. NBER Working Paper 16919. March 2011.

9. Ferrantino M. J., Wang Z. Accounting for Discrepancies in Bilateral Trade: the Case of China, Hong Kong, and the United States // China Economic Review. 2008. Vol.19. Pp. 502-520.

10. Greaney T.M., Li Y. Assessing Foreign Direct Investment Relationships between China, Japan, and the United States // Journal of Asian Economics. 2009. Vol. 20. Pp. 611625.

11. International Trade Statistics Yearbook 2010. URL: http://comtrade.un.org/pb/ (дата обращения: 05.09.2011).

12. $\mathrm{Li} X$., $X u$ D. Impact of RMB Appreciation on Trade and Labor Markets of China and the USA: A Multi-country Comparative General Equilibrium Model // China and World Economy. 2011. Vol. 19. № 2. Pp. 19-39.

13. Liao W., Shi K., Zhang Z. Vertical Trade and China's Export Dynamics. HKIMR Working Paper №10/2010. April 2010. 25 p.

14. McKinnon R., Schnabl G. China and its Dollar Exchange Rate: A Worldwide Stabilizing Influence? CESifo Working Paper № 3449. May 2011.

15. Sun J. Retrospect of the Chinese Exchange Rate Regime after Reform: Stylized Facts during the Period from 2005 to 2010 // China \& World Economy. 2010. Vol. 18. № 6. Pp. 19-35.

16. Taiwan Bureau of foreign trade. URL: http://eweb.trade.gov.tw (дата обращения: 20.09.2011).

17. Thorbecke $W$. Investigating the Effect of Exchange Rate Changes on China's Processed Exports // Journal of The Japanese and International Economies. 2011. Vol. 25. Pp. 33-46.

18. Whalley J., Xin X. China's FDI and Non-FDI Economies and the Sustainability of Future High Chinese Growth // China Economic Review. 2010. Vol. 21. Pp. 123-135.

19. World Economic Outlook Database, April 2011. URL: http://www.imf.org/external/ pubs/ft/weo/2011/01/ weodata/weoselser.aspx?c=924\&t=1 (дата обращения: 16.09.2011).

20. Xing $Y$. Foreign direct investment and China's bilateral intra-industry trade with Japan and the US // Journal of Asian Economics. 2007. Vol. 18. Pp. 685-700. 